\title{
Seekers of the spiritual art and higher wisdom
} Encounters between art and esotericism

$\mathrm{T}$ he current issue of Approaching Religion is based on a two-day seminar arranged in Helsinki in August 2020 by the Signe and Ane Gyllenberg Foundation under the title 'Clear-sighted Art - Open Mind? Encounters between Art and Esotericism'. The seminar was arranged as a pendant to the art exhibition The Path to Hidden Knowledge that was open in the foundation's museum, Villa Gyllenberg, from June to October (see Camilla Granbacka's review in this issue). The organising committee of the seminar included Siiri Oinonen and Lotta Nylund from the Gyllenberg Foundation as well as Nina Kokkinen, who also curated the art exhibition, and Ruth IIIman as academic representatives.

The great mysteries of life and death have always fascinated and inspired artists. Art and creation have offered opportunities to deal with the meaning of life, the constitution of reality and the inevitability of death. For many artists, esotericism and various forms of alternative spirituality have offered fruitful fora in which to contemplate and express these questions and to look for personally meaningful answers. Hence, the organisers envisioned a seminar that would target these essential questions as they emerge in the interface between art and research. The seminar dealt with the many different ways in which art and esotericism can be interwoven, focusing on questions such as: How have themes, motifs and symbols been used to express esoteric ideas? Can the creation of art be perceived as a spiritual exercise in itself? For what kind of political and personal goals have artists made use of, for example, Anthroposophy, Theosophy or Spiritualism? Can the encounter between art and esotericism create spiritual and physical well-being?

The first day of the seminar brought together a cross-disciplinary group of researchers - representing for example the study of religions, art and cultural history, literature, theology and architecture - for a roundtable seminar at the museum Villa Gyllenberg. Selected papers from this roundtable have been edited into the research articles published in this issue. The second day was dedicated to an open symposium at the Amos Rex Museum, featuring dialogues between artists, authors and scholars dedicated to the field of art and esotericism and attracting a large and engaged audience (see Maarit LeskeläKärki's review in this issue).

The issue opens with an article by the guest editor of this issue, Nina Kokkinen. In her article Kokkinen examines the relationship between art and esotericism by utilizing the concept of seeker. Artists interested in esotericism do not always engage 
in any of its movements or currents but approach it more loosely and emphasise the importance of seeking personal answers and meaning - this is also the case for many of the artists discussed in this issue. According to Kokkinen, seekership opens up a new and meaningful way of looking at artists' agency and relationship to esotericism. The following article pertains to the same theme but focuses on the context of literature. Viola Parente-Čapková analyses Finnish literature from around the turn of the nineteenth and the twentieth centuries, outlining how the theme of seekership is portrayed in novels by L. Onerva and Eino Leino.

Marja Lahelma examines a five-part relief series entitled The Development of the Human Soul created by the Finnish artist Sigrid af Forselles. Af Forselles can be seen as a typical seeker: even if esotericism plays a central role in her art, the artist never committed herself to any esoteric movement. Lahelma argues that the prominent theme in af Forselles monumental artwork is spiritual evolution or development typical of esoteric discourses. The following article also presents a female artist for whom esotericism became relevant, as Per Faxneld discusses the Swedish Tyra Kleen. Faxneld's specific focus is Kleen's way of situating herself in relation to the esoteric idea of the 'artist as magus'. Kaisa Broner's article highlights the relationship between esotericism and artistic work. It sheds light on the design method of Reima Pietilä, one of Finland's most significant architects. Pietilä himself called the method 'shamanistic', and it involved many ideas and practices related to esotericism, nature mysticism, and clairvoyance. In Mikko Välimäki's article the art of Finnish Oscar Parviainen is analysed in the context of early twentieth century occulture and Decadence.
Laura Hellsten contributes to this issue with an article focusing on the art form of dance. She presents an ethnographic study of dance within the frames of the Swedish Lutheran Church and poses the question whether this can be seen as a contemplative practice. Sari Kuuva, for her part, ponders the themes she describes as 'religious' or 'spiritual' in the art made by the patients in the Nikkilä Psychiatric Hospital founded in the 1910s. Art was part of Nikkiläs rehabilitation programme as early as in the 1930s. Among other things, Kuuva's article raises an interesting and complex question about what kind of art could and should be defined as 'religious', 'spiritual', or 'esoteric'.

These research articles are followed by two review articles presenting artist biographies and the life and works of two female painters for whom esotericism offered an important source of inspiration. Sanna Ryynänen presents the little-known Finnish artist Meri Genetz, who was wellversed in most of the prominent strands of esotericism popular in the first part of the twentieth century and continued her seekership throughout her career as a painter. In Karin Ström Lehander's article, the light is yet again turned to the artist Tyra Kleen, whose life and esoteric seekership is traced chronologically as a red thread throughout her biography.

The issue concludes with a substantial review section, opened by Maarit Leskelä-Kärki, who reflects on the symposium 'Clear-sighted Art - Open Mind? Encounters between Art and Esotericism' and its fruits. Camilla Granbacka, for her part, reviews the art exhibition The Path to Hidden Knowledge that paralleled the symposium. Finally, three book reviews of recently published literature pertaining to the field of art and esotericism, are presented by Hedvig Martin, Tiina Mahlamäki and Tiina Sepp. Martin reviews the book 
Spiritual Treasures, which was published in connection to the exhibition The Path to Hidden Knowledge and thus forms yet another significant part of the Gyllenberg foundation's tripartite project.

The starting point for the project was a desire better to understand the worldview of Signe and Ane Gyllenberg, the founders of the Gyllenberg Foundation. Both of them were Anthroposophists and Ane was a well-known and highly appreciated Freemason, too. The exhibition, symposium and related publications have made visible the importance of esotericism in the field of Finnish art. This special issue of Approaching Religion is an academic endpoint for the project. It brings new insights into the relationship between Nordic and especially Finnish artists and esotericism. In addition, it provides some new conceptual openings and interesting material for reflection on when and how it really makes sense to talk about art and esotericism - or better yet 'esoteric art'. How exactly can esotericism relate to art? And what is its relationship to, for example, alternative spirituality, contemplation, or shamanism? In recent years, the study of art and esotericism has become increasingly popular. This has made it all the more important to reflect on the overall basis, theoretical starting points, and theoretical concepts used in the field of art and esotericism. We hope this thematic issue of Approaching Religion can offer some new openings for these discussions.
Dr Nina Kokkinen is a researcher (University of Turku) working in the fields of art history and the study of religion. She has specialised in discourses relating to esotericism and alternative spirituality particularly in modern art. In her doctoral dissertation (2019) she studied the idea of 'sacred, spiritual art' at the turn-of-twentieth-century Finland and developed the concepts of occulture and seekership for the study of art and religion. In addition to her award-winning Totuudenetsijät ('Truth-seekers', Vastapaino 2019) she has edited books and thematic issues on the history of esotericism and its relation to art. She has also written numerous articles on the subject and brought the results of her research to the attention of the wider public in the art exhibitions she has curated.

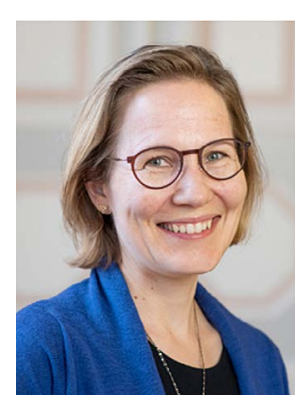

Ruth IIIman is the Director of the Donner Institute for Research in Religion and Culture in Åbo/Turku, Finland and a docent of the study of religion at Åbo Akademi University and of the history of religions at Uppsala University. Her main research interests include contemporary Judaism, interreligious dialogue and cultural encounters as well as religion and the arts. 